\title{
Metabolic resistance mechanism in Aedes aegypti from Lagos State, Nigeria
}

\author{
Ifeoluwa Kayode Fagbohun ${ }^{1 *}$, Emmanuel Taiwo Idowu', Abiodun Kanmi Olakiigbe ${ }^{2}$, Amos Tolulope Oyeniyi ${ }^{2}$,
} Olubunmi Adetoro Otubanjo ${ }^{1}$ and Taiwo Samson Awolola ${ }^{2}$

\begin{abstract}
Background: Aedes aegypti transmits several arboviral diseases of global public health threat such as dengue, zika, and yellow fever. Recently, a series of yellow fever outbreaks have been reported in different parts of the country. Globally, the control of mosquito-borne diseases has relied heavily on insecticides based vector control efforts. Therefore, we assessed the susceptibility status to three different classes of WHO approved insecticides and evaluated the importance of detoxifying enzymes on insecticides resistance in Aedes aegypti collected from Lagos State, Nigeria. Aedes aegypti immature stages were collected from suitable habitats in peri-domestic areas of Alimosho, Kosofe, Badagry, and Ibeju-Lekki Local Government Areas (LGAs) of Lagos State, 2-5 days old glucose-fed adult female mosquitoes were exposed to discriminating doses of DDT, permethrin, bendiocarb, and PBO synergist using WHO standard procedure and kits. Identification was through morphological means only.

Results: Resistance to DDT and permethrin was recorded in all the LGAs, suspected resistance to bendiocarb was recorded in Aedes aegypti from Alimosho while full susceptibility was recorded in other LGAs. PBO synergist significantly increases the $24 \mathrm{~h}$ mortality of DDT and permethrin-resistant Aedes aegypti in all the LGAs. The activities of both GSTs and cytochrome P450s increase with decreasing mortality for Aedes aegypti, regression value $\left(R^{2}\right)$ ranges from 0.8889 to 0.6224 for GSTs and 0.4379 to 0.616 for cytochrome P450s.

Conclusions: Aedes aegypti population from Lagos State, Nigeria, have developed resistance to DDT and permethrin, the activities of P450s and GST were implicated in DDT and permethrin resistance in this study. Therefore, a need for regular insecticides monitoring and PBO should be incorporated into Aedes aegypti insecticides control strategies to forestall development of resistance to DDT and pyrethriods.
\end{abstract}

Keywords: Aedes aegypti, DDT, Pyrethroid, PBO synergist, Metabolic resistance

\section{Background}

Aedes aegypti is the main vector of Yellow fever virus, dengue virus (DENV), chikungunya virus (CHIKV), and zika virus (ZIKV); this mosquito has been a source of global public health concern with the increasing prevalence and incessant outbreaks of yellow fever virus, dengue, and zika virus (WHO, 2017). Aedes aegypti is found in close proximity with humans, and lays its eggs in mainly artificial containers commonly found in domestic and peri-domestic areas, such as water-storage

\footnotetext{
* Correspondence: fagbohunife@gmail.com

${ }^{1}$ Department of Zoology, University of Lagos, Akoka, Yaba, Lagos, Nigeria Full list of author information is available at the end of the article
}

containers, flower pots, discarded plastics, and automobile tyres. The risk of Aedes aegypti borne infection is particularly high in several parts of Nigeria especially Lagos State, where there is a proliferation of urban slums due to increasing population and lack of adequate planning and amenities. In 2019, there were several reported cases of yellow fever outbreak in some states in Nigeria and at least a suspected case of the infection in all the states, 48 yellow fever-related death cases were recorded in four states between the months January and July in Nigeria (NCDC, 2019). Insecticides-based vector control measures have been vital in the management and reduction of mosquito borne diseases globally, though the development and spread of 
insecticides resistance in different mosquito species of public and veterinary health importance has had significantly negative impact on this progress (Hemingway \& Ranson, 2000; WHO, 2017). Resistance to different classes of insecticides has been reported in Aedes aegypti from different parts of the world (Moyes et al., 2017; Weetman et al., 2018). Resistance mechanisms in mosquitoes can be mediated by the combination of mutation in the target site, increased activities of metabolic enzymes, physiological adaptation, and behavioral changes (Liu, 2015; Moyes et al., 2017; Smith, Kasai, \& Scott, 2016). Pyrethroids and DDT metabolic insecticides resistance mechanism in Aedes aegypti has often been associated with elevated activities/overexpression of cytochrome P450 monooxygenases (P450s), carboxylesterases (ESTs), and glutathione-S-transferases (GSTs) (Brengues et al., 2003; Harris, Rajatileka, \& Ranson, 2010; Smith et al., 2016). The importance of detoxifying enzymes in Aedes resistance to different classes of insecticides has been emphasized in several previous studies in various parts of the world (Bingham, Strode, Tran, Khoa, \& Jamet, 2011; Ishak, Riveron, Ibrahim, \& Stott, 2016; Kamgang, Yougang, Tchoupo, Riveron, \& Wondji, 2017; Li et al., 2018). Piperonyl butoxide (PBO) insecticide synergist is a non-toxic compound that interferes with the ability of P450s in insects to metabolize insecticides (Bingham et al., 2011). Studies in Africa and other parts of the world have shown higher mortality in insecticides resistant Aedes pre-exposed to PBO synergist (Bingham et al., 2011; Kamgang et al., 2017; Kumar et al., 2002; Smith, Kasai, \& Scott, 2018). In Nigeria, there is paucity of information on the susceptibility status of Aedes aegypti to the different classes of neurotoxic insecticides used in public health, as most of mosquito insecticides studies are focused on the malaria vectors. This study is therefore aimed at determining the current insecticides resistance status of Aedes aegypti to three insecticides of different classes and also evaluating the activities of P450s and GST in insecticides resistant Aedes aegypti.

\section{Materials and methods Study area}

The study was carried out in four Local Government Areas (LGAs) of Lagos State, southwestern Nigeria. Comprising of two densely populated LGAs: Alimosho LGA, and Kosofe LGA; and two less densely populated LGAs: Ibeju-Lekki LGA situated within the southern area of Lagos State, just below the Lagos lagoon and Badagry LGA, a coastal town located between Metropolitan Lagos and the border with Republic of Benin.

\section{Study design}

Aedes aegypti immature stages were located from water pots, tyre holes, abandoned wells, and suitable larval habitats in peri-domestic areas of the four surveyed LGAs. They were collected separately in well labelled containers and transferred to the insectary of the University of Lagos and allowed to develop to adult stage under suitable insectary conditions $\left(27^{\circ} \mathrm{C} \pm 2{ }^{\circ} \mathrm{C}\right.$ and relative humidity $80 \% \pm 10 \%)$. Insecticides susceptibility assay, $\mathrm{PBO}$ assay, and morphological identification was carried out at the Zoology laboratory of the University of Lagos. Biochemical assays were carried out at the vector research unit of the Nigeria Institute of Medical Research (NIMR), Yaba, Lagos, Nigeria.

\section{Insecticide and PBO synergist bioassay}

The tests were performed using WHO test filter paper impregnated with the selected insecticides and piperonyl butoxide (PBO) impregnated papers obtained from the Vector Control Research Unit (VCRU), University Sains Malaysia (http:/www. inreskit.usm.my). Non-blood fed, 2-3 days old laboratory emerged adult female mosquitoes were exposed to DDT (4\%) and permethrin (0.75\%) WHO insecticide-treated paper.

A total of 25 female mosquitoes were pre-exposed to $4 \%$ piperonyl butoxide (PBO) for $1 \mathrm{~h}$ using four replicates. Thereafter, PBO-treated mosquitoes were exposed to either DDT (4\%) or Permethrin $(0.75 \%)$ for another 1 h. Each experiment consisted of four replicates. Knockdown rates of mosquitoes were recorded at intervals for one hour, mosquitoes were later transferred into holding tubes with untreated papers, allowed a 24-h recovery period and were supplied with a $10 \%$ sugar meal during this period after which mortality was recorded. All the bioassays were accompanied by negative control.

\section{Microplate metabolic enzyme activity assay}

Eight (8) adult female mosquitoes that were pre-exposed to a WHO insecticide test paper were homogenized singly in $200 \mu \mathrm{L}$ of cold distilled water in a $1.5 \mathrm{~mL}$ centrifuge tube. The homogenate was centrifuged at $14,000 \mathrm{rpm}$ for $20 \mathrm{~s}$. The supernatant was stored at $-20^{\circ} \mathrm{C}$ (Hemingway 1998). Two metabolic enzymes; Cytochrome $\mathrm{P} 450$ monooxygenase (P450s) and Glutathione S-transferase (GSTs) were analyzed on individual insecticide-resistant females mosquitoes, and on the laboratory susceptible strain according to WHO protocols (Hemingway 1998). Mean absorbance values for each tested mosquito and enzyme were converted into enzyme activity and standardized based on the total protein amount.

\section{Glutathione S-transferase assay}

This test was carried out in two replicates, $10 \mu \mathrm{l}$ of mosquito homogenate were placed in separate wells of the microtitre plate, $200 \mu \mathrm{l}$ of the GSH/CDNB working solution was then added. Three plate blanks containing $10 \mu \mathrm{l}$ distilled water and $200 \mu \mathrm{l}$ of the GSH/CDNB working solution were used per microtitre plate. The test was then left at room temperature for $20 \mathrm{~min}$, and the absorbance value was read at $340 \mathrm{~nm}$. 
Table 1 The probit knockdown time (KDT 50 and $\mathrm{KDT}_{95}$ ) values and percentage mortality of Aedes aegypti to DDT, permethrin, and PBO synergist in Lagos State

\begin{tabular}{|c|c|c|c|c|c|}
\hline Location & Number exposed & $\mathrm{KDT}_{50}(95 \% \mathrm{cl})$ & $\mathrm{KDT}_{95}(95 \% \mathrm{cl})$ & Mortality (\%) & $P$ value \\
\hline \multicolumn{6}{|l|}{ Kosofe } \\
\hline DDT & 100 & 116.7(88.9-188.1) & 552.2(300-1672.3) & 26 & \multirow[t]{2}{*}{0.000} \\
\hline $\mathrm{PBO}+\mathrm{DDT}$ & 100 & $54.8(48.4-56.2)$ & $257.4(182.4-425.9)$ & 75 & \\
\hline PER & 100 & 113.6(86.7-181.1) & 599.3(321.1-1826.3) & 29 & \multirow[t]{2}{*}{0.000} \\
\hline$P B O+P E R$ & 100 & $50.1(43.4-60.7)$ & 369.3(233.6-747.2) & 78 & \\
\hline \multicolumn{6}{|l|}{ Alimosho } \\
\hline DDT & 100 & $91.8(62.7-284.4)$ & 444(181.3-8502.7) & 46 & \multirow[t]{2}{*}{0.000} \\
\hline $\mathrm{PBO}+\mathrm{DDT}$ & 100 & 86.7(71.1-117.6) & $416.3(256.1-918.2)$ & 91 & \\
\hline PER & 100 & $46.3(41.5-61)$ & $222.4(162.1-350)$ & 62 & \multirow[t]{2}{*}{0.004} \\
\hline $\mathrm{PBO}+\mathrm{PER}$ & 100 & $15.5(14.1-24.5)$ & $86.7(58.1-204.2)$ & 99 & \\
\hline \multicolumn{6}{|l|}{ Ibeju-Lekki } \\
\hline DDT & 100 & $150.1(103.5-307.3)$ & $965.1(424.3-4938.2)$ & 20 & \multirow[t]{2}{*}{0.000} \\
\hline $\mathrm{PBO}+\mathrm{DDT}$ & 100 & $50.7(50.3-58.4)$ & 218.3(161.2-336.6) & 76 & \\
\hline PER & 100 & $45(40-51.6)$ & $226.6(179.5-407.5)$ & 70 & \multirow[t]{2}{*}{0.03} \\
\hline$P B O+P E R$ & 100 & $32.3(25.3-427)$ & 108.9(70.3-303.7) & 99 & \\
\hline \multicolumn{6}{|l|}{ Badagry } \\
\hline DDT & 100 & 118.4(87.5-200.7) & 848.3(409-3182.6) & 26 & \multirow[t]{2}{*}{0.000} \\
\hline $\mathrm{PBO}+\mathrm{DDT}$ & 100 & $28.1(26.5-29.7)$ & $61.6(56-69.2)$ & 100 & \\
\hline PER & 100 & $48(41.8-57.9)$ & 145.5(104.8-257.2) & 65 & \multirow[t]{2}{*}{0.03} \\
\hline $\mathrm{PBO}+\mathrm{PER}$ & 100 & $28.1(26.5-29.7)$ & $61.6(58-69.2)$ & 92 & \\
\hline
\end{tabular}

Mortality of $>98 \%$ indicates susceptibility, 97-90 suspected resistance and < 90\% resistant (WHO, 2016); S susceptible, SR suspected resistance, $R$ resistant

\section{Cytochrome P450 monooxygenase assay}

Two microliters of mosquito homogenate was placed in separate wells of a microplate, $80 \mu \mathrm{l}$ of $0.625 \mathrm{M}$ potassium phosphate $(\mathrm{pH} 7.2)$ was added to each replicate, $200 \mu \mathrm{l}$ of the mixture of $5 \mathrm{ml}$ methanol solution of tetramethyl benzidine with $15 \mathrm{ml}$ of $0.25 \mathrm{M}$ sodium acetate buffer ( $\mathrm{pH}$ 5.0) was added to each well, $25 \mu \mathrm{l}$ of $3 \%$ hydrogen peroxide was also added to each replicate, the preparation was left for $2 \mathrm{~h}$ at room temperature before reading of absorbance at $650 \mathrm{~nm}$. Control was run at $20 \mu \mathrm{l}$ of distilled water instead of mosquito homogenate and the assay was carried out in two replicates.

\section{Protein assay}

Total protein was measured for each mosquito using Biuret test. All measurements were done in duplicate.
Protein concentration in sample was calculated as: absorbance of sample/absorbance of standard multiplied by concentration of standard $(60 \mathrm{~g} / \mathrm{dl})$. Enzyme activities were calculated as $\mathrm{nmol} / \mathrm{g} / \mathrm{dl}$ protein.

\section{Data analysis}

Insecticides susceptibility was classified based on the criteria that $98-100 \%$ mortality of mosquitoes implies susceptibility, 80-97\% mortality indicates possible resistance that needs to be further confirmed via biochemical or molecular assays and $<80 \%$ mortality implies resistance (WHO, 2016). Regression probit was used to compute the $\mathrm{KDT}_{50}$ and $\mathrm{KDT}_{95}$. Chi-square was used to compare percentage mortality between insecticide only and PBO plus insecticide. Regression analysis

Table 2 The probit knockdown time (KDT 50 and $\left.\mathrm{KDT}_{95}\right)$ values and percentage mortality of mosquito exposed to bendiocarb (0.1\%) in Lagos State, Nigeria

\begin{tabular}{|c|c|c|c|c|c|c|}
\hline Location & Number exposed & $\mathrm{KDT}_{50}(95 \% \mathrm{cl})$ & $\mathrm{KDT}_{95}(95 \% \mathrm{cl})$ & $\%$ KD $60 \mathrm{~min}$ & Mortality (\%) 24 h & Status \\
\hline Kosofe & 100 & $28(26.5-29.5)$ & $55(51-61)$ & 99 & 100 & S \\
\hline Alimosho & 100 & $26.6(25-28.2)$ & $60.6(54.9-68.3)$ & 96 & 97 & SR \\
\hline Ibeju-Lekki & 100 & $22.3(21.1-23.6)$ & $45.8(42-50.9)$ & 96 & 100 & $S$ \\
\hline Badagry & 100 & 22.3(20.9-25.8) & $38.1(33.1-47.3)$ & 100 & 100 & $\mathrm{~S}$ \\
\hline
\end{tabular}

Mortality of $>98 \%$ indicates susceptibility, 97-90 suspected resistance and < 90\% resistant (WHO, 2016); S susceptible, SR suspected resistance, $R$ resistant 

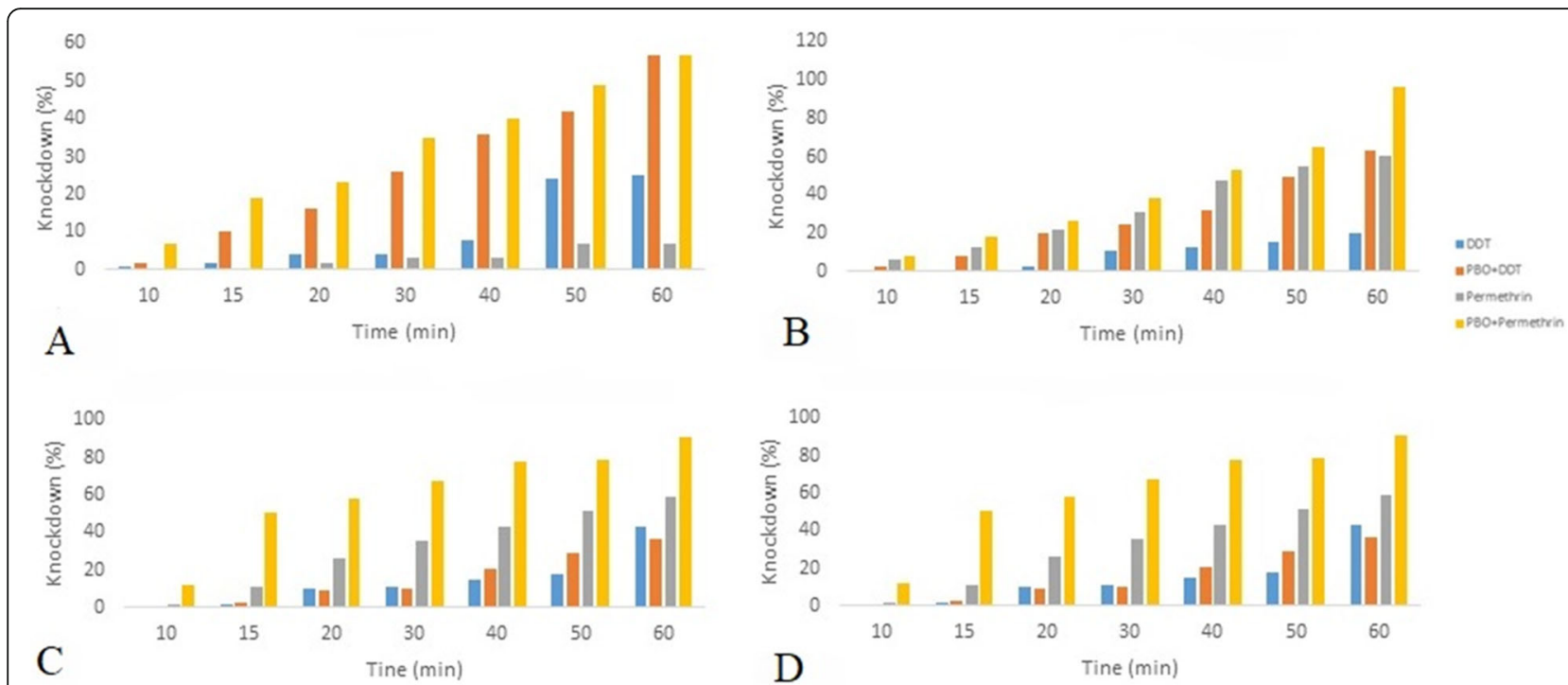

Fig. 1 a-d Percentage knockdown time comparison of Aedes aegypti between PBO synergized and non-synergized assay in Kosofe, Ibeju-Lekki, Alimosho, Badagry LGAs

was used to compute the association between percentage mortality of mosquitoes and the activities of detoxifying enzymes. All data analyses were computed using Microsoft Excel version 2016 and IBM SPSS Statistics 23. $P$ was considered significant at $P<0.05$.

\section{Results}

Aedes aegypti from the four surveyed LGAs showed high level of resistance to DDT and permethrin with $24 \mathrm{~h}$ percentage mortality ranging from 20 to $46 \%$ and 29 to $70 \%$, respectively. The estimated knockdown time (KDT) for $50 \%$ Aedes aegypti to exposed DDT was lowest in Alimosho LGA (91.8 $\mathrm{min}$ ) and highest in Ibeju-Lekki
LGA (150.1 min), similarly $\mathrm{KDT}_{95}$ was lowest in Alimosho LGA (444min) and highest in Ibeju-Lekki LGA (965.1 min). $\mathrm{KDT}_{50}$ and $\mathrm{KDT}_{95}$ for permethrin was reduced as compared to DDT, ranging from 45 to 113.6 min for $\mathrm{KDT}_{50}$ and 145.5-599.3 min for $\mathrm{KDT}_{95}$ (Table $1)$. In this study, full susceptibility to bendiocarb was recorded in Kosofe, Ibeju-Lekki, and Badagry LGAs while possible resistance to bendiocarb was reported in Alimosho LGA (Table 2). PBO synergist significantly $(P<$ 0.05) reduces the level of resistance of Aedes aegypti to DDT and permethrin in all surveyed locations, likewise the $\mathrm{KDT}_{50}$ and $\mathrm{KDT}_{95}$ for $\mathrm{PBO}$ synergized bioassays were lower compared to that of non-synergized

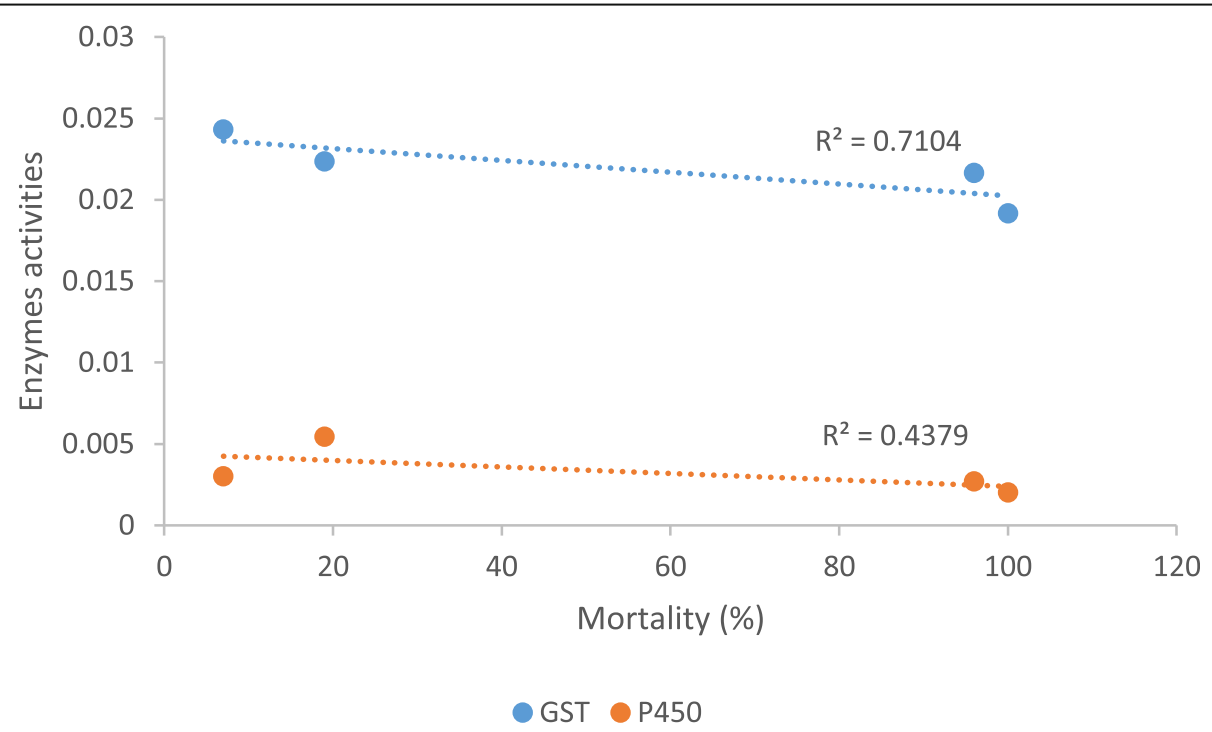

Fig. 2 Regression of mortality rate of Aedes aegypti exposed to DDT and mean level enzymes activity in four LGAs from Lagos state, Nigeria 


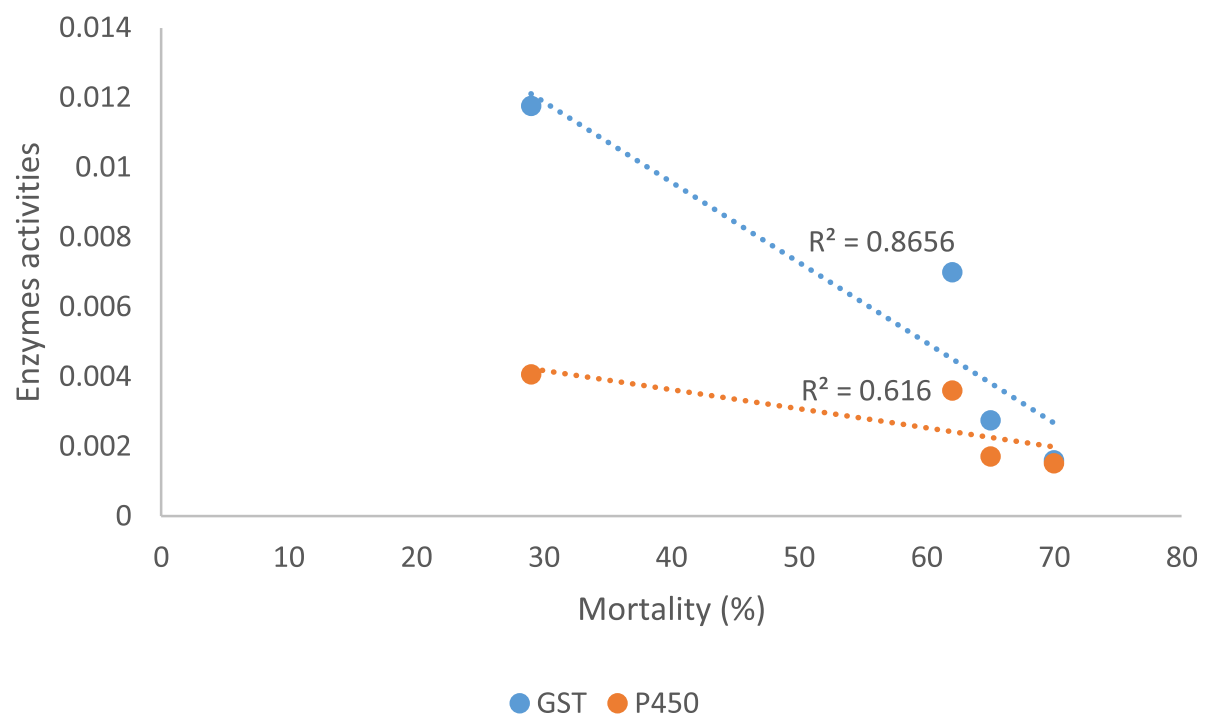

Fig. 3 Regression of mortality rate of Aedes aegypti exposed to permethrin and mean level enzymes activity in four LGAs from Lagos state, Nigeria

bioassays (Table 1). The mean progressive knockdown of both PBO synergized and non-synergized of Aedes aegypti are shown in Fig. 1a-d with the PBO synergized assay showing faster knockdown compared to nonsynergized assay. Figure 2 shows the relationship between $24 \mathrm{~h}$ percentage mortality of DDT-resistant Ae. aegypti from Lagos State and the activities of detoxifying enzymes. Figure 3 also shows the association between the percentage mortality of permethrin-resistant Aedes aegypti and the mean level of detoxifying enzymes activities in the four studied LGAs. The activities of both GSTs and cytochrome P450s increases with decreasing mortality for Ae. aegypti, regression value $\left(R^{2}\right)$ ranges from 0.8889 to 0.6224 for GSTs and 0.4379 to 0.616 for cytochrome P450s.

\section{Discussion}

This study provides information on the susceptibility status of dengue and yellow fever vector to three different classes of insecticides and also provides insight into the biochemical resistance mechanisms of this mosquito in Lagos State.

In this study, resistance to DDT was recorded in all the four surveyed LGAs similar to a previous report from three LGAs in Lagos State between 2011 and 2012 (Ayorinde, Oboh, Oduola, Otubanjo, \& Zhu, 2015), Aedes aegypti resistance to DDT has also been recently reported in Umudike, southeastern Nigeria (Ukpai \& Ekedo, 2018) and Cameroon (Kamgang et al., 2011; Kamgang et al., 2017). Though the level of $24 \mathrm{~h}$ percentage resistance and knockdown time recorded in this study was higher than that of previous studies in different areas of Lagos State and Cameroon (Ayorinde et al.,
2015; Kamgang et al., 2011). Pyrethroid resistance was recorded in all the study areas in this study, similar to previous studies in Lagos and Kwara States, Nigeria, reported susceptibility of Aedes aegypti to permethrin (Ayorinde et al., 2015; Oduola, Obembe, Adelaja, \& Ande, 2016), though suspected resistance to deltamethrin has been reported in Lagos (Ayorinde et al., 2015) and Umudike, (Ukpai \& Ekedo, 2018) both in the southern part of Nigeria. Pyrethroids resistance in Aedes aegypti has also been previously reported in Cameroon (Kamgang et al., 2011; 2017), Burkina Faso (Badolo et al., 2019), Malaysia (Ishak et al., 2017), and several other parts of the world. Selection pressure as a result of indiscriminate usage of insecticides for agricultural, domestic, and public health purposes has been associated with DDT and pyrethroids resistance in mosquitoes (Awolola et al., 2007; Fagbohun, Oyeniyi, Idowu, Otubanjo, \& Awolola, 2019; Kamgang et al., 2011). The increased level of insecticides resistance recorded in this study may be a result of increase in the deployment of insecticide based measures in the control measures for the control of malaria vectors in the study locations.

In this study, susceptibility to bendiocarb was recorded in three of the four surveyed LGAs namely; Kosofe, Badgry and Ibeju-Lekki while suspected resistance was reported in Alimosho LGA. Similar studies have reported Aedes aegypti susceptibility to carbamates in Umudike, southeastern Nigeria (Ukpai \& Ekedo, 2018) and Cameroon (Kamgang et al., 2011) while carbamates resistance has been previously reported in Kwara State, Nigeria (Oduola et al., 2016), Burkina Faso (Badolo et al., 2019), Indonesia (Hamid et al., 2018), and Sri Lanka (Leong, Vythilingam, Wee, Liew, \& Wong, 2019). 
PBO synergist was able to significantly increase the 24-h percentage and also reduce the knockdown time of Aedes aegypti to DDT and permethrin in this study; previous studies in different parts of the world have demonstrated the efficacy of PBO synergists in the management of insecticides resistant vectors. $\mathrm{PBO}$ is well known for its ability to inhibit the activities of P450s in insects and has been used in combination with insecticides for several mosquito control tools (Fagbohun et al., 2019). Similar previous studies in some parts of Africa have confirmed the efficacy of $\mathrm{PBO}$ synergists in controlling DDT and pyrethroids resistant Aedes mosquitoes (Badolo et al., 2019; Kamgang et al., 2017).

The mean enzymes activities of GST and P450s were inversely correlated to the 24-h percentage mortality of $\mathrm{Ae}$ des aegypti to DDT and permethrin, indicating lower mortality rate with increasing activities of GST and P450s in this study. As recorded in this study, previous studies have linked the activities of GST and P450s to DDT and pyrethriods resistance in Aedes (Brengues et al., 2003; Ishak et al., 2016; Leong et al., 2019; Li et al., 2018).

\section{Conclusion}

Findings from this study is very timely, considering the recent outbreaks of Aedes-borne diseases in several parts of Nigeria, the study has been able to provide the current resistance profile of Aedes aegypti in Lagos State, Nigeria, and also highlighted the importance of GSTs and P450s resistance mechanisms in the areas. We recommend regular insecticides monitoring and the use of PBO-based insecticides control tools in Aedes aegypti control in Lagos State, Nigeria.

\section{Abbreviations}

GSTs: Glutathione S-tranferases; LGAs : Local Government Areas; P450: Cytochrome P450 mono-oxygenase; PBO: Piperonyl butoxide; SDGs: Sustainable Development Goals; WHO: World Health Organization

\section{Acknowledgements}

We wish to acknowledge the support and contributions from the technical staff of vector research unit, Nigeria Institute of Medical Research (NIMR), Yaba, Lagos.

\section{Authors' contributions}

FIK, OAK, and OAT carried out the field and laboratory studies. IET, OOA, and ATS designed and supervised the study. FIK carried out the data analysis and wrote the first manuscript draft. OAK, OAT, and IET critically reviewed the manuscript. All authors read and approved the final manuscript.

\section{Funding}

This work was supported by the central research grant of the University of Lagos, Nigeria CRC 2017/08.

\section{Availability of data and materials}

Data generated during this study are included in this published article and also available upon request at the vector research laboratory of Nigeria Institute of Medical Research (NIMR), Lagos.

Ethics approval and consent to participate

Not applicable
Consent for publication

Not applicable

\section{Competing interests}

The authors declare that they have no competing interests.

\section{Author details}

${ }^{1}$ Department of Zoology, University of Lagos, Akoka, Yaba, Lagos, Nigeria.

${ }^{2}$ Vector Research Unit, Nigeria Institute Medical Research, Yaba, Lagos,

Nigeria.

Received: 5 December 2019 Accepted: 18 September 2020

Published online: 29 September 2020

\section{References}

Awolola, T. S., Oduola, A. O., Oyewole, I. O., Obansa, J. B., Amajoh, C. N., Koekemoer, L. L., \& Coetzee, M. (2007). Dynamics of knockdown pyrethroid insecticide resistance alleles in a field population of Anopheles gambiae s.s. in southwestern Nigeria. Journal of Vector Borne Diseases, 44, 181-188.

Ayorinde, A., Oboh, B., Oduola, A., Otubanjo, O., \& Zhu, C. (2015). The insecticide susceptibility status of aedes aegypti (Diptera: Culicidae) in Farm and Nonfarm Sites of Lagos State, Nigeria. Journal of Insect Science, 15, 2-5. https://doi.org/10.1093/jisesa/iev045.

Badolo, A., Sombie, A., Pignatelli, P. M., Sanon, A., Yameogo, F., Wangrawa, D. W., .. Weetman, D. (2019). Insecticide resistance levels and mechanisms in Aedes aegypti populations in and around Ouagadougou, Burkina Faso. PLoS One, 13, 1-17.

Bingham, G., Strode, C., Tran, L., Khoa, P. T., \& Jamet, H. P. (2011). Le butoxyde de pipéronyl peut-il améliorer l'efficacité des pyréthroïdes contre Aedes aegypti résistant aux pyréthroïdes? Tropical Medicine and International Health, 16, 492-500. https://doi.org/10.1111/j.1365-3156.2010.02717.x.

Brengues, C., Hawkes, N. J., Chandre, F., Mccarroll, L., Duchon, S., Guillet, P., .. Hemingway, J. (2003). Pyrethroid and DDT cross-resistance in Aedes aegypti is correlated with novel mutations in the voltage-gated sodium channel gene. Medical and Veterinary Entomology, 17, 87-94.

Fagbohun, I. K., Oyeniyi, T. A., Idowu, T. E., Otubanjo, O. A., \& Awolola, S. T. (2019). Cytochrome P450 Mono-Oxygenase and Resistance Phenotype in DDT and Deltamethrin-Resistant Anopheles gambiae ( Diptera : Culicidae ) and Culex quinquefasciatus in Kosofe, Lagos, Nigeria. Journal of Medical Entomology, 56, 817-821. https://doi.org/10.1093/jme/tjz006.

Hamid, P. H., Ninditya, V. I., Prastowo, J., Haryanto, A., Taubert, A., \& Hermosilla, C. (2018). Current Status of Aedes aegypti Insecticide Resistance Development from Banjarmasin , Kalimantan, Indonesia. BioMed Research International, 1-7. https://doi.org/10.1155/2018/1735358.

Harris, A. F., Rajatileka, S., \& Ranson, H. (2010). Pyrethroid Resistance in Aedes aegypti from Grand Cayman. The American Journal of Tropical Medicine and Hygiene, 83, 277-284. https://doi.org/10.4269/ajtmh.2010.09-0623.

Hemingway, J., 1998. Insecticide resistance mechanisms (Field and laboratory manual), (pp. 1-39). Geneva: World Health Organisation.

Hemingway, J., \& Ranson, H. (2000). Insecticide resistance in insect vectors of human disease. Annual Review of Entomology, 45, 371-391.

Ishak, I. H., Kamgang, B., Ibrahim, S. S., Riveron, J. M., Irving, H., \& Wondji, C. S. (2017). Pyrethroid resistance in Malaysian populations of dengue vector aedes aegypti is mediated by CYP9 family of cytochrome P450 genes. PLOS Neglected Tropical Diseases, 11, 1-20. https://doi.org/10.1371/journal.pntd. 0005302.

Ishak, I. H., Riveron, J. M., Ibrahim, S. S., \& Stott, R. (2016). The cytochrome P450 gene CYP6P12 confers pyrethroid resistance in kdr -free Malaysian populations of the dengue vector Aedes albopictus. Scientific Reports, 6, 113. https://doi.org/10.1038/srep24707.

Kamgang, B., Marcombe, S., Chandre, F., Nchoutpouen, E., Nwane, P., Etang, J., ... Paupy, C. (2011). Insecticide susceptibility of Aedes aegypti and Aedes albopictus in Central Africa. Parasites \& Vectors, 4, 79. https://doi.org/10.1186/ 1756-3305-4-79.

Kamgang, B., Yougang, A. P., Tchoupo, M., Riveron, J. M., \& Wondji, C. (2017). Temporal distribution and insecticide resistance profile of two major arbovirus vectors Aedes aegypti and Aedes albopictus in Yaoundé, the capital city of Cameroon. Parasites \& Vectors, 10, 1-9. https://doi.org/10.1186/ s13071-017-2408-X.

Kumar, S., Thomas, A., Sahgal, A., Verma, A., Samuel, T., \& Pillai, M. K. K. (2002). Effect of the synergist, piperonyl butoxide, on the development of 
deltamethrin resistance in yellow fever mosquito, Aedes aegypti L. (Diptera: Culicidae). Arch. Insect Biochem. Physiol., 50, 1-8. https://doi.org/10.1002/arch. 10021.

Leong, C. S., Vythilingam, I., Wee, J., Liew, K., \& Wong, M. L. (2019). Enzymatic and molecular characterization of insecticide resistance mechanisms in field populations of Aedes aegypti from Selangor. Parasites \& Vectors, 1-17. https://doi.org/10.1186/s13071-019-3472-1.

Li, Y., Xu, J., Zhong, D., Zhang, H., Yang, W., Zhou, G., ... Chen, X. G. (2018). Evidence for multiple-insecticide resistance in urban Aedes albopictus populations in southern China. Parasites \& Vectors, 11, 1-10. https://doi.org/ 10.1186/s13071-017-2581-y.

Liu, N. (2015). Insecticide Resistance in Mosquitoes: Impact, Mechanisms, and Research Directions. Annual Review of Entomology, 60, 537-559. https://doi. org/10.1146/annurev-ento-010814-020828.

Moyes, C. L., Vontas, J., Martins, A. J., Ng, L. C., Koou, S. Y., Dusfour, I., ... Weetman, D. (2017). Contemporary status of insecticide resistance in the major Aedes vectors of arboviruses infecting humans. PLoS Neglected Tropical Diseases, 11, 1-20. https://doi.org/10.1371/journal.pntd.0005625.

NCDC, 2019. Yellow fever monthly situation report in NIGERIA.

Oduola, A. O., Obembe, A., Adelaja, O. J., \& Ande, A. T. (2016). Surveillance and insecticide susceptibility status of Culicine mosquitoes in selected communities utilizing long-lasting insecticidal nets in Kwara State, Nigeria. Animal Research International, 13, 2483-2491.

Smith, L. B., Kasai, S., \& Scott, J. G. (2016). Pyrethroid resistance in Aedes aegypti and Aedes albopictus : Important mosquito vectors of human diseases. Pesticide Biochemistry and Physiology, 133, 1-12. https://doi.org/10.1016/j. pestbp.2016.03.005.

Smith, L. B., Kasai, S., \& Scott, J. G. (2018). Voltage-sensitive sodium channel mutations S989P + V1016G in Aedes aegypti confer variable resistance to pyrethroids, DDT and oxadiazines. Pest Management Science, 74, 737-745. https://doi.org/10.1002/ps.4771.

Ukpai, M. O., \& Ekedo, M. C. (2018). Insecticide susceptibility status of Aedes aegypti in Umudike, Nigeria. Animal Research International., 15, 3082-3089.

Weetman, D., Kamgang, B., Badolo, A., Moyes, C. L., Shearer, F. M., Coulibaly, M., ... McCall, P. J. (2018). Aedes Mosquitoes and Aedes -Borne Arboviruses in Africa : Current and Future Threats. Int. J. Environ. Res. Public Health, 15, 1-20. https://doi.org/10.3390/ijerph15020220.

WHO (2016). Test procedures for insecticide resistance monitoring in malaria vector mosquitoes, World Health Organisation Technical Report Series. https://doi. org/10.1007/978-3-642-10565-4.

WHO (2017). Global vector control response 2017-2030. Geneva: World Health Organization.

\section{Publisher's Note}

Springer Nature remains neutral with regard to jurisdictional claims in published maps and institutional affiliations.

\section{Submit your manuscript to a SpringerOpen ${ }^{\circ}$ journal and benefit from:}

- Convenient online submission

- Rigorous peer review

- Open access: articles freely available online

- High visibility within the field

- Retaining the copyright to your article

Submit your next manuscript at $\boldsymbol{\nabla}$ springeropen.com 